\title{
DIGITÁLNÍ KOMPETENCE V TRANSDISCIPLINÁRNÍM NAHLÉDNUTÍ: MEZI FILOSOFIÍ, SOCIOLOGIÍ, PEDAGOGIKOU A INFORMAČNÍ VĚDOU
}

ČERNÝ, M. 2019. Digitální kompetence v transdisciplinárním nahlédnutí: mezi filosofí, sociologií, pedagogikou a informační vědou. Brno: Masarykova univerzita. 190 s. ISBN 978-80-210-9330-0.

V současném komplexním světě se jeví nezbytným, aby vědní disciplíny navzájem komunikovaly a obohacovaly se. Vzájemná inspirace mưže přinést, při vědomí všech rizik, novou kvalitu. Text Michala Černého (2019b) s podtitulem slibujícím propojení filozofie, sociologie, pedagogiky a informační vědy nad aktuálním tématem digitálních kompetencí se proto může jevit jako slibný počin. Zároveň je tento text téměř nerecenzovatelný, protože autor knihy i jeho recenzent by v ideálním př́ípadě měli být odborníky ve všech dotčených vědách. My však $\mathrm{k}$ recenzi přistoupíme jinak. Jsme si vědomi našich limitů, naše formální školení se omezuje na pedagogické vědy, resp. pedagogiku a andragogiku (a také sociologii, které jsme se však dále soustředěněji nevěnovali). Proto zde nechceme a ani nemůžeme hodnotit každé vyjádření autora ani celkové propojení daných čtyř věd, jde nám spíše o to, jak autor reflektuje právě pedagogiku a andragogiku. Ostatně sociologie se v textu nijak výrazněji nepromítla, což by mohlo být naší první výhradou. Pohříchu ne poslední.

I pohledu pedagogického a andragogického je $\mathrm{v}$ textu žalostně málo. $\mathrm{V}$ kontextu věd o výchově nalézáme $\mathrm{v}$ textu průběžně drobné zmínky a odkazy na některé teoretiky (Průcha, Jarvis, Knowles, Freire, Illich), které ale pocházejí především ze sekundárních zdrojů (např. Freire z interpretace Brdičkovy) a jsou vytržené z původního kontextu. To má tři efekty. Za prvé je to nepochopení původního autorova díla či myšlenky (např́íklad Knowles je tu vykreslen téměř jako zastánce behaviorismu), za druhé přisouzení určitých konceptů nesprávným autorům (Jarvis zcela jistě nevytvořil koncept 
informační společnosti či vývoje společnosti od industriální k učící se). Třetím, největším problémem jsou ovšem určité „zkratky“ způsobené právě tím, že autor vytrhuje myšlenky z původních souvislostí a spojuje je s dalším textem tak, že přestávají dávat smysl nebo působí přinejmenším zmatečně. Namátkou vybíráme například: „Informační společnost je především společností občanskou“ (s. 59) či „Jedním z klíčových rysů informační společnosti je, že není možné si vystačit sám“ (s. 62).

Kromě těchto drobnějších průběžných zmínek pak nacházíme určité propojení s vědami o výchově v kapitole Řešení problémů, v krátkých pasážích s názvy „Nalezení mezer v digitálních kompetencích“, „Propojené učeni“ a „Nové kompetence, nové perspektivy“. Zde musíme vyjádřit pochybnost o autorově erudici v oblasti pedagogických věd a o jeho pochopení základních konceptů a východisek. Už tvrzení „Jedním ze základních východisek andragogiky, ale také ohniskem svárů je to, co by se dospělý člověk měl učit“ (str. 132) je snadné vyvrátit. Obsahy vzdělávání jsou pro andragogiku - mimo veškerou pochybnost - marginálním tématem. Nebo se snad autor domnívá, viz další text daného odstavce, že obsahy vzdělávání a smysl vzdělávání jsou totéž? Tak či onak, teorie i praxe vzdělávání dospělých obsahy v podstatě neřeší, někdy snad i ke své škodě. Dalším příkladem autorovy neznalosti může být výrok: „,...] oblast sociálně patologických jevů v kyberprostředí [...] je téma, které je $\mathrm{v}$ teoretickém diskursu, ale také $\mathrm{v}$ pedagogické komunitě reflektováno zřejmě nejvíce.“ Ne, není. Při jednoduchém hledání podle klíčových slov ve světových databázích dostaneme řádově více odkazů s kombinací slov „učení“ a „online“ nebo „počítač“ atd. než např. bullying a tatáž slova. Čtenář Brdičky by tohle opravdu měl vědět.

Zdá se, že se chytáme jednotlivých vět. Ničeho jiného se ovšem „chytit“ nelze, protože takto je kniha napsaná. Odstavce jsou často poskládané z jednotlivých výroků, až by se nám chtělo říct, že troška toho školometského strukturování odstavce na vymezení - výklad - shrnutí by textu výrazně prospěla. Nezbývá tedy než vzít tyto jednotlivé věty a podrobit je kritickému přezkoumání. Mohli bychom tak pokračovat ve výčtu autorových omylů (,... směr, který například v pedagogice není zatím téměř reflektovaný - jde o učící se komunity“), dezinterpretací („Nejlépe se něco naučíme, když něco děláme, ř́ká tradiční úsloví, které stálo jako jeden z motivů tzv. reformních pedagogik na začátku 20. století“), floskulí („Ostatně v pedagogice můžeme hovořit o osobním vzdělávacím prostředí...") a oslích můstků („V pedagogickém kontextu jsou důležité...“). V jedné věci je ovšem autor 
Digitální kompetence v transdisciplinárním nahlédnutí: mezi filosofií, ...

konzistentní. V jeho představě jsou pedagogické vědy v principu normativní (např. „Z pedagogiky pak vyvstává potřeba jistého nepřetržitého učení se..."). Tady se Černý s vývojem pedagogiky časově míjí přinejmenším o celé dekády. Jak jsme již uvedli, pedagogiky (a andragogiky) je $\mathrm{v}$ textu opravdu poskrovnu. Zaslouží si tato kniha vůbec svůj podtitul? Z hlediska pedagogiky nikoliv. Při čtení však vyvstává ještě jedna otázka: Co je vlastně smyslem knihy a pro jakého čtenáře je určena? Z původního konceptu DigComp, který je základem pro strukturu knihy, zbyly jen názvy kapitol, zbytek jsou volné asociace na dané téma, věty s různou tematikou, které jsou nahodile poskládány k sobě - autor např́klad spojuje stvoření světa, tedy Starý zákon, Nietzscheho („Podle Nietzscheho je člověk zvíře, které může slíbit“), knihtisk, programátorské jazyky, lidovou tvořivost a možnost psaní díky internetu ve třech odstavcích (s. 75). Jinde je otevřenost jako jeden z principů DigComp velmi nejasně spojena s celoživotním rozvojem a konceptem radosti a hédonismu Teilharda de Chardin (s. 26 a 27).

Je opravdu těžké $v$ textu najít něco, u čeho bychom se mohli pozastavit alespoň s dílčím uspokojením. Snad konstatování, že „Knowles propaguje striktně lineární přístup k učení..." bychom mohli kvitovat s povděkem. Není to sice myšlenka nijak originální a slušelo by se to přiznat, ale $\mathrm{v}$ českém kontextu je užitečné si ji zopakovat. V diskusích o sebeřízeném učení se toto téma objevuje už několik desetiletí a některé analýzy dotyčné Knowlesovy teze spojují s první fází vývoje uvažování o sebeřízeném učení. Autor však tyto diskuse bud' nepovažuje za podstatné, nebo je nezná, protože ve výkladu přeskakuje $\mathrm{k}$ dalšímu volně navazujícímu tématu.

Vzhledem $\mathrm{k}$ našemu nekompromisnímu hodnocení textu se cítíme povinováni položit si otázku, zda zde není nějaká polehčující okolnost vysvětlující zjevné nedostatky textu. Není autorův přístup dán charakterem tohoto konkrétního textu či tématu? Není jeho prostor k vyjádření limitovaný, a tudíž je nucen uchylovat se ke zkratkám, které se někdy objeví v každém textu (ano, ani naše texty samožrejmě nejsou dokonalé!). Šli jsme tedy i mimo rámec recenzované knihy a rozhlédli jsme se po Černého textech, které mají už podle titulu ambici vyjadřovat se k pedagogickým vědám.

Jeden z nich jsme našli v časopise Paidagogos (Černý, 2019a) a nese název „Analýza některých přístupů $\mathrm{k}$ autonomii učení $\mathrm{v}$ perspektivě moderních edukačních technologií: setkání pedagogiky a andragogiky?“. Autor si v něm klade otázku, „zda reflexe autonomie v učení může představovat klíc, který bude sbližovat andragogické a pedagogické pojetí učení. Černý nedefinuje, 
co je ono pojetí učení, ani neuvádí, proč ho zajímá sbližování andragogiky a pedagogiky. Jeho postup je takový, že bere jednu (!) tezi z Beneše (kromě jednoho elementárního odkazu na Knowlese a poněkud zmatečného odkazu na Jarvise skrze sekundární pramen je to jediný meritorní odkaz k andragogické literatuře), kterou mylně vydává za reprezentaci andragogického myšlení. Tu zdánlivě rozporuje. To mu umožňuje libovolně řetězit témata, takže glosuje Finka a Kanta, proplete heutagogiku s konektivismem, odbočí k autonomnímu učení se cizím jazykům, ke „kokurikulu“ atd. a text ponechá bez závěru (jakkoliv pasáž nazvaná závěr zde je).

Další Černého text tohoto charakteru jsme našli v časopisu ProInflow (Černý, 2016) pod názvem „Finální antropický princip ve filosofii, pedagogice a informační vědě“. Autorova vyjádření k finálnímu antropickému principu nám nepř́sluší hodnotit, je to mimo naši odbornost. Hlavní tezí textu ve vztahu k pedagogickým vědám je normativně formulovaná věta: „Jakkoli je finální antropický princip kontroverzním a problematickým konceptem, představuje zajímavý stimul pro filosofii, pedagogiku i informační vědu.“ $\mathrm{K}$ tomu lze jen dodat, že děkujeme za podnět, ale je zde celá řada méně kontroverzních konceptů, kterým nejspíš dáme přednost, protože v nich - na rozdíl od onoho principu - vidíme vazbu na předmět pedagogických věd.

Našli jsme také Černého (2019c) recenzi textu Slavíka a kolektivu (Slavík, Janík, Najvar, \& Knecht, 2017). Zajímavostí je, že časopis Pedagogická orientace k této recenzi připojil i reakci autorského kolektivu (Slavík, Janík, \& Najvar, 2019). Budeme-li abstrahovat od tématu, Černého vyjadřování je v recenzi o poznání kultivovanější než v ostatních námi glosovaných textech. Přesto má s nimi mnohé společné rysy a také obsahuje zmatečné glosy typu „didaktika je oproti filosofii př́liš praktická“. Všechny komentované Černého texty spojují podle našeho názoru podobné charakteristiky: fragmentarizace; zaplavování textu filozofickými prameny (aț už je to Teilhard de Chardin, Fink, Kant, Nietzsche či další), které nejsou propojeny s tím, o čem autor píše; častá práce se sekundárními zdroji; časté využívání floskulí a „zkratek“, které mají místo spíše v publicistice.

Nad autorem, který se chlubí řadou monografií, snad není třeba lámat hůl. Jeho texty mohou být, při vědomí jejich limitů, užitečné. Černý rád upozorňuje na nová témata a koncepty, rád používá soudobé pojmosloví, byt ne vždy se znalostí věci. Nicméně $\mathrm{v}$ momentech, kdy se věnuje soustředěnému čtení spíše než volnému psaní, jeho recenze mohou přimět autory k zamyšlení (viz laskavá a přemýšlivá reakce Slavíkova týmu). Řečeno na okraj, těžko 
pochopit, proč autor „ozvláštňuje“ své texty psaním v plurálu či vybočováním z jazykového úzu („dimense“, „filosofie“, „basální“, „organisace“, zároveň však „remixování obsahu“, „tweetování“, „technostres“). Jinde zase mluví o „problem solvingu“, i když existuje přesný překlad („řešení problémů“) askutečně tu není žádná terminologická záludnost.

Je ale také dobré si povšimnout, kdo publikaci recenzoval a který nakladatel knihu vydal. Týž nakladatel Černému vydal např. knihu Pedagogicko-psychologické otázky online vzdělávání, aniž by se autor mohl pochlubit odborností v oboru psychologie. Kým tedy vlastně Michal Černý je? Podle jeho internetové stránky je mj. filozofem výchovy a informace, kosmologem, informačním vědcem, pedagogem, didaktikem, historikem a publicistou. Doufáme, že alespoň něčím z toho opravdu je. V jeho odbornost v pedagogických vědách či alespoň schopnost se přibližně správně vyjádřit k pedagogice či andragogice $z$ dobrých důvodů nevěříme.

\section{LITERATURA}

Černý, M. (2016). Finální antropický princip ve filosofii, pedagogice a informační vědě. ProInflow: Časopis pro informační vědy, 8 (1), 103-116.

Černý, M. (2019a). Analýza některých př́stupů k autonomii učení v perspektivě moderních edukačních technologií: setkání pedagogiky a andragogiky? Paidagogos, 14 (2), 5-34.

Černý, M. (2019b). Digitální kompetence v transdisciplinárním nahlédnutí: mezi filosofí, sociologií, pedagogikou a informační vědou. Brno: Masarykova univerzita.

Černý, M. (2019c). Slavík, J., Janík, T., Najvar, P., \& Knecht, P. (2017). Transdisciplinární didaktika: o učitelském sdílení znalostí a zvyšování kvality výuky např́íc obory. Pedagogická orientace, 29 (3), 366-373.

Slavík, J., Janík, T., \& Najvar, P. (2019) K recenzi Transdiciplinární didaktiky slovo autorů. Pedagogická orientace, 29 (3), 374-381.

Slavík, J., Janík, T., Najvar, P., \& Knecht, P. (2017). Transdisciplinární didaktika: o učitelském sdílení znalostí a zvyšování kvality výuky napřič obory. Brno: Masarykova univerzita. 


\section{Autoři recenze}

doc. Mgr. Petr Novotný, Ph.D.

PhDr. Miroslava Dvořáková, Ph.D.

Masarykova univerzita, Filozofická fakulta, Ústav pedagogických věd, Arna Nováka 1, 602 00, Brno, Česká republika

email: novotny@phil.muni.cz,mirka.dvorakova@mail.muni.cz

Přijato: 27. 7. 2020

Link to this article: https://doi.org/10.11118/lifele20201003355 